\title{
RECOGNITION, MEASUREMENT AND DISCLOSURE OF FINANCIAL INSTRUMENTS ACCORDING TO INTERNATIONAL FINANCIAL REPORTING STANDARDS (IFRS)
}

\author{
Professor PhD Tatiana Danescu, tatiana_danescu@yahoo.com \\ Assistant PhD Student Ovidiu Spatacean, spatacean_ioanovidiu@yahoo.com \\ “Petru Maior" University Targu Mures
}

\begin{abstract}
From investors' perspective, appropriate recognition and measurement of financial instruments strengthened by accurate disclosures of information related to investments in financial instruments, allow a comprehensive view upon financial position, financial performances and changes in financial position, particularly for publicly traded companies listed on a stock exchange.

For the purpose of this paper, appropriate and accurate refer to an IFRS reporting basis and the requirements that financial statements are prepared in accordance with a set of qualitative attributes, designed to offer a true and fair view of the financial position and performances of the securities issuers.
\end{abstract}

\section{Concepts related to financial instruments}

The financial instruments ${ }^{1}$ are represented by any contract that generates simultaneously a financial asset for an entity and a financial liability or an instrument of owners' equity for another entity.

IAS 32 Financial Instruments: Presentation establishes some principles regarding the classification and presentation of financial instruments, as well as some conditions in which the net settlement of the financial assets and financial liabilities is admitted. From this International Accounting Standard's perspective, the issuer of a financial instrument will classify its components, at the initial recognition as a financial liability, a financial asset or an instrument of owners' equity, according to the content of the contractual commitment and to the definitions of the financial liabilities, the financial asset and the instrument of owners' equity.

At the same time, this International Accounting Standard establishes a clear delimitation between an instrument of owners' equity and a financial liability, respectively a contractual obligation for the entity to deliver either cash or another financial asset, or to change financial assets or liabilities under unfavorable conditions for the entity. In this sense, there are exemplified the preferred stock with the clause of necessary redemption embedded, or other financial instruments which can be liquidated before the falling due, a covenant that confers the owner the right to deliver them back to the issuer in exchange of either cash or other financial asset.

Regarding the composed financial instruments (hybrids), the issuer will evaluate the terms of these contracts in order to determine if they contain both a liability and a component of owners' equity, which have to be presented and disclosed separately. For example, a bond or another similar financial instrument convertible by the owner into an exact number of common stock issued by the entity contains both a component of financial liability (a contractual commitment to deliver cash or other financial asset) and an instrument of owners' equity (a CALL option which confers the owner the right to exercise it in an exact number of capital stock during a specified period of time). From

\footnotetext{
${ }^{1}$ IAS 32 "Financial Instruments: presentation”, Paragraph 11.
} 
the perspective of the accounting treatment, when initially recognizing a composed financial instrument, its accounting value is allocated to the components of the owners' equity and financial liabilities, without the entity recognizing involved losses or gains. Furthermore, the component of owners' equity is considered to be the residual value, after deducting from the right value of the financial instrument as a whole, the value determined separately for the liability component.

IAS 32 Financial Instruments: Presentation permits an entity to operate compensations between an asset and a financial liability, with the presentation of the net value in a balance sheet only when the entity has a legal right to make compensations between the recognized values and intends either to liquidate the financial liability on a net basis, or to convert the asset into cash and to liquidate the liability on a simultaneous basis.

\section{Recognition, de-recognition and measurement of the financial instruments}

\subsection{Initial recognition of a financial instrument}

IAS 39 Financial Instrument: Recognition and Measurement establishes the criteria which has to be fulfilled by a financial asset or a financial liability, so that an entity could recognize them in a balance sheet, respectively only when the entity becomes part at the contractual arrangements of the financial instrument.

\subsection{De-recognition and transfer of a financial asset. De-recognition of a financial liability}

An entity should de-recognize a financial asset only when the contractual rights upon cash flows, which derive from the financial asset, expire or when the entity transfers the financial asset and this transfer qualifies for de-recognition. In the spirit of IAS 39 Financial Instrument: Recognition and Measurement, the entity transfers a financial asset only if a transfer occurs related to the contractual rights to collect the cash flows generated by that financial asset or the entity retains such contractual rights, but assumes a contractual obligation to pay cash flows to one or more beneficiaries.

Canceling the initial recognition of a financial liability involves extracting that financial liability from one entity's balance sheet and occurs only when this is liquidated, that is when the obligation specified in the contract is achieved, cancelled or expired. From this point of view, an exchange of debt instruments with substantially different conditions or a substantial change of the conditions of a financial liability must be accounted as a liquidation of the initial financial liability and recognition of a subsequent financial liability.

\subsection{Measurement of financial instruments}

\subsubsection{Initial measurement of financial assets and financial liabilities}

When initially recognized, a financial asset or a financial liability will be measured at fair value, including the costs of the transaction which can be directly assigned to the acquisition or the issue of the financial asset or financial liability, when these are designated at their fair value in the profit and loss account (e.g. held for trading).

\subsubsection{Subsequent measurement of financial assets and financial liabilities}

Subsequent measurement of the financial assets, including derivatives recognized as financial assets, is achieved by referring to their fair value, excepting the following categories of financial assets: 
loans and receivables issued by an entity, respectively investments held until maturity date, which are measured at amortized cost, using the effective interest method, by discounting future incash flows, during the whole expected life of the financial instrument, to the carrying value of the financial asset.

$\checkmark$ investments in owners' equity instruments that do not have a public price listed on a active market, therefore the fair value can not be measured on reliable basis, as well as derivatives related to and settled through such unlisted instruments of owners' equity. This category of financial investments is measured at cost.

After the initial recognition, an entity will measure financial debts at the amortized cost by using the effective interest method, less:

$\checkmark$ Financial debts measured at fair value in the profit and loss account, including derivative instruments which represent debts. They are measured at fair value, excepting a derivative debt instrument that is related and must be liquidated by delivering unlisted instruments of owners' equity and is associated to a fair value not been estimated in a credible manner. This one should be measured at cost.

$\checkmark$ Financial debts resulting when a transfer of a financial asset does not qualify for derecognition or is accounted by using the "continuous implication" approach.

$\checkmark$ Financial warrant contracts and financial agreements adjusted under the market level for interest rate, which are measured at highest value considering the value determined according to IAS 37 Provisions, Contingent Liabilities and Contingent Assets and the initially recognized value, less accumulated amortization recognized according to IAS 18 Revenue.

The financial assets and liabilities designated as hedged instruments or for risk hedging operations ${ }^{2}$ constitute the object of measurement according to the requirements of hedge accounting regarding the exposure of an entity to the variation of fair value, respectively to variation of cash flows or against the risks of a net investment in a foreign operation defined according to IAS 21 The effects of changes in foreign exchange rates.

To sum up, measurement of the financial instruments according to their classification can be reflected as it follows:

\footnotetext{
${ }^{2}$ According to IAS 39 Financial Instruments: recognition and measurement, an element covered against the risks is an asset, a liability, a firm commitment, an anticipated transaction or a net investment in a foreign operation, which expose the entity at the risk of the variations of fair value or cash flows and it is classified as being covered against risk. From the perspective of an covering relation, an instrument for covering against risks represents a derivative instrument or a financial asset or a financial liability which is not a derivative (only to cover the risk of variation related to exchange rates); their fair value or cash flows are predicted to compensate the variations of fair value or of cash flows related to an instrument designated as covered against risks.
} 


\section{Table no 1:}

Measurement of the Financial Instruments

\begin{tabular}{|c|c|c|}
\hline $\begin{array}{c}\text { Categories of } \\
\text { financial instruments }\end{array}$ & Description & Measur ement techniques \\
\hline $\begin{array}{l}\text { Financial instruments } \\
\text { issued by the entity }\end{array}$ & $\begin{array}{l}\text { Receivables and loans issued by the entity by } \\
\text { providing cash, goods or services. }\end{array}$ & $\begin{array}{l}\text { Measurement at amortizable cost, } \\
\text { tested periodically for } \\
\text { impairment. }\end{array}$ \\
\hline $\begin{array}{l}\text { Investments held until } \\
\text { maturity }\end{array}$ & $\begin{array}{l}\text { Investments in financial instruments with } \\
\text { fixed falling due, which the entity intends and } \\
\text { is capable to keep up until the falling due. }\end{array}$ & $\begin{array}{l}\text { Measurement at amortizable cost, } \\
\text { tested periodically for } \\
\text { impairment. }\end{array}$ \\
\hline $\begin{array}{l}\text { Available-for-sale } \\
\text { financial investments }\end{array}$ & $\begin{array}{l}\checkmark \text { Investments with fixed falling due, which } \\
\text { the entity does not intend or is not capable to } \\
\text { keep up until the falling due; } \\
\checkmark \text { Investments in instruments of owners' } \\
\text { equity, non-traded on a stock exchange. } \\
\checkmark \text { Investments in instruments of owners' } \\
\text { equity, non-traded on a stock exchange, but a } \\
\text { fair value can be accurately estimated. } \\
\checkmark \text { Investments in instruments of owners' } \\
\text { equity, non-traded on a stock exchange and for } \\
\text { which there can not be estimated a real value. }\end{array}$ & $\begin{array}{l}\text { Measurement at fair value by } \\
\text { reflecting the modification in: } \\
\text { - profit and loss account; } \\
\text { - owners' equity, until the sale or } \\
\text { the disposal of the financial } \\
\text { assets, in which moment the } \\
\text { differences of value are } \\
\text { transferred to net profit or loss of } \\
\text { the period. } \\
\text { Measurement at cost, tested } \\
\text { riodically for depreciation. }\end{array}$ \\
\hline $\begin{array}{l}\text { Financial instruments } \\
\text { held for trading } \\
\text { (designated at fair } \\
\text { value through profit } \\
\text { and loss account) }\end{array}$ & $\begin{array}{l}\text { Financial assets acquired for the only purpose } \\
\text { to generate profit during a short period of time } \\
\text { as an effect of the price fluctuation or from } \\
\text { the margin restrained by the dealer. Derivative } \\
\text { instruments are always considered to be held } \\
\text { for trading if they are not recognized as } \\
\text { effective instruments for covering risks. }\end{array}$ & $\begin{array}{l}\text { Measurement at fair value and } \\
\text { reflecting the variation in the net } \\
\text { profit or loss of the period. }\end{array}$ \\
\hline
\end{tabular}

\section{Disclosure of information and valuating the impact upon financial position and performances}

IFRS 7 Financial Instruments: Disclosures is focused on an entity's requirements to offer in their financial statements disclosures of information which allow the external users to valuate:

A. The importance of possessing financial instruments for the financial position and performances.

From this perspective, in order to describe the financial position of the entity, in the financial statements there should be provided adequate and relevant information related to the carrying values of the following categories of financial assets and liabilities:

$>$ Financial assets and financial liabilities measured at fair value through profit or loss account, by presenting separately those designated accordingly at the initial recognition and those classified as held for transactional purposes. If the entity designates a financial liability as measured at fair value through profit or loss account, accurate presentations related to the variation of financial liability's fair value caused by the default risk, should be made. Also, disclosure should be made as to reflect the difference between the liability's carrying value and the value that must be disbursed at the falling due by the entity;

$>$ Investments kept until the falling due (held up to maturity);

$>$ Loans and receivables, including the maximum level of exposure to the default risk, the value any derivative instruments diminish this exposure, as well as the variation of the loan or receivables' fair value, respectively of the derivative instruments related to those. In case of some 
failings caused by an entity non-executions or encroachments upon the obligations related to loan repayments, there will be provided appropriate details of any non-executions of the obligations regarding the principal, the interest, the sinking fund or the repayment requirements, corroborated with information regarding the carrying value of the loans for which the cove nants have not been respected, inclusively regarding the possible remedies or re-negotiations of the repayment requirements, before having the financial statements authorized for issuance;

$>$ Available- for- sale financial assets;

$>$ Financial liabilities measured at amortized cost.

The financial performances of an entity, associated with the possession of financial instruments, are described by presenting in the financial statements (profit and loss account or explanatory notes and accounting policies) the information related to the following categories of revenues and expenses, respectively gains and losses:

$>$ Net gains or losses associated with the financial assets or financial liabilities designated at fair value through profit or loss account; available-for-sale financial assets; investments held until the falling due, respectively the loans and receivables or financial liabilities measured at amortized cost;

$>$ Revenues and expenses regarding the interests (determined using the effective-interest method), associated with the financial assets or financial liabilities that are not designated at fair value through profit or loss account;

$>$ Revenues and expenses regarding fees generated by financial assets or financial liabilities that are not designated at fair value through profit or loss account, respectively by activities of asset management;

$>$ Impairment losses for each class of financial assets.

B. The nature and the amplitude of the risks rising from the financial instruments, at which the entities are exposed during the reporting period and at its end, as well as the proper manner in which the entities manage those type of risks.

In order to comply with these requirements, entities will provide both qualitative information (details about the exposure to risks and the factors that generated them, respectively the objectives, strategies and policies, as well as the process of risk management and methods or techniques used to valuate and control them) and the quantitative information regarding the exposure to risks (especially the default risk, the liquidity risk and the market risk).

\section{Bibliography:}

1. IFRS 7 Financial Instruments: Disclosures;

2. IAS 32 Financial Instruments: Presentation;

3. IAS 39 Financial Instruments: Recognition and Measurement;

4. Barry J. Epstein, Abbas Ali Mirza: Interpretation and Application of International Accounting and Financial Reporting Standards, BMT Publishing House, 2005;

5. Hennie van Greuning: International Financial Reporting Standards - A practical guide, The World Bank\& IRECSON Institute, 2005;

6. www.iasb.org 